\title{
PENERAPAN LOCATION BASED SERVICED (LBS) DALAM PROTOTIPE PENGENALAN RUANGAN DENGAN METODE EXTREME PROGRAMMING
}

\author{
Viktor Handrianus Pranatawijaya ${ }^{\text {a,1,*}}$ \\ ${ }^{a}$ Universitas Palangka Raya, Kampus Tunjung Nyaho Jalan Yos Sudarso, Palangka Raya, Kalimantan Tengah, Indonesia \\ ${ }^{1}$ viktorhp@it.upr.ac.id
}

\section{ARTICLE INFO}

\section{Keywords}

Location Based Service (LBS)

Geographic Information System (GIS)

Google Map Application Programming Interface (API).

Ruangan

Extreme Programming

\begin{abstract}
Location Based Service (LBS) is a service to provide information that has been created, compiled, selected or filtered by considering the location of users or other people or current mobile devices [1]. It is possible to implement LBS using GPS because mobile devices have GPS services [6]. Based on these services, making an application for room recognition can be done by utilizing the Google Maps API by implementing GIS, LBS, and GPS.

Implementation of application with extreme programming methods is carried out in accordance with the stages. In the planning part, an analysis is carried out on the business needs and user stories, in the design, use case diagrams and activity diagrams are made, coding is done by implementing the design using the mobile programming language, and testing is done using black box testing.

The application of LBS is carried out when calling the room information page which functions to find the location of the room and displays notifications and room information when the user enters the radius that has been determined in the room data. Determining the radius is very important to do so that the information about the room that is displayed does not overlap with other rooms. This is done to keep the room information displayed to the user only to display information about one room only. Therefore, when determining the radius of the room, it must be determined carefully so that the radius can create a circle that does not intersect with other radius circles. The room information displayed is obtained from data management by the admin through the building management page, rooms, and items. In managing, admins can add, edit, and delete data.
\end{abstract}

\section{Pendahuluan}

Location Based Service (LBS) merupakan suatu layanan untuk memberikan informasi yang telah dibuat, disusun, dipilih atau disaring dengan mempertimbangkan lokasi pengguna atau orang lain atau perangkat mobile saat ini [1]. Pengguna ponsel dapat mencari dan mengukur posisi pengguna untuk mendapatkan informasi berdsarkan lokasi dan dapat dilihat dengan memanfaatkan layanan Geographic Information System (GIS). Dua unsur utama dari LBS adalah [2] (1) Location Manager (API Maps) dengan menyediakan perangkat bagi sumber atau source untuk LBS, Application Programming Interface (API) Maps menyediakan fasilitas untuk menampilkan atau memanipulasi peta dan (2) Location Providers (API Location) dengan menyediakan teknologi pencarian lokasi yang digunakan oleh perangkat. API Location berhubungan dengan data GPS dan data lokasi real-time. Lokasi, perpindahan, serta kedekatan dengan lokasi tertentu dapat ditentukan melalui Location Manager.

Informasi pada masa sekarang sangat erat kaitannya dengan media digital yang memungkinkan terjadinya kombinasi antara informasi teks, dan gambar. Informasi berupa data geografis yang ada sekarang pun dimungkinkan untuk terintegrasi dengan data lain sehingga informasi yang didapat menjadi lebih baik dan dapat digunakan sesuai dengan kebutuhan [3]. Dengan berkembangnya bahasa pemrograman maka GIS pun dapat menjadi lebih interaktif karena pengguna dapat melihat detil suatu 
tempat beserta informasi mengenai tempat tersebut pada peta. Peta dibuat dengan memanfatkaan layanan dari Google Map API.

Suatu fasilitas untuk mengetahui sebuah informasi gedung, ruangan, dan barang telah dikembangkan dengan menggunakan pemetaan yang memanfaatkan Google Map API [4]. Untuk mengoptimalkan penyampaian informasi ruangan dengan mudah maka dapat diterapkan LBS sehingga pada saat melewati ruangan dalam radius tertentu maka dapat menampilkan informasi ruangan tersebut secara otomatis. Menurut Kamus Besar Bahasa Indonesia [5] ruangan adalah tempat yang lega, kamar (besar), bilik (dalam rumah), kelas (tempat belajar), tempat dalam kapal (perahu), tempat muatan; palka. Penyajian ruang ujian pun pernah dilakukan dengan memanfaatkan LBS [6].

Oleh sebab itu, penerapan LBS dengan menggunakan Global Positioning System (GPS) dimungkinkan dilakukan karena perangkat mobile memiliki layanan GPS [6]. Berdasarkan layanan tersebut maka dalam pembuatan aplikasi untuk pengenalan ruangan dapat dilakukan dengan memanfaatkan Google Maps API dengan menerapkan GIS, LBS, dan GPS.

\section{Metodologi Penelitian}

Dalam penelitian penulis menggunakan beberapa tahap penelitian yaitu :

\subsection{Tahap Studi Pustaka dan Observasi}

Metode ini melakukan studi pustaka terhadap buku dan jurnal ilmiah sebagai pendukung dalam penelitian tentang GIS, LBS, GPS. Observasi dilakukan untuk mengambil data-data mengenai ruangan pada penelitian ini. Pengumpulan data dalam proses penelitian merupakan suatu kegiatan yang sangat penting untuk mendapatkan informasi yang dibutuhkan sesuai dengan tujuan penelitian [7]. Data yang digunakan untuk ruangan dapat dilihat pada tabel 1,2, dan 3 .

Tabel 1. Tabel gedung

\begin{tabular}{ll}
\hline \multicolumn{2}{c}{ column_name } \\
\hline id_gedung & int \\
\hline nama_gedung & varchar \\
\hline tipe & varchar \\
\hline luas & double \\
\hline kondisi & varchar \\
\hline lokasi & text \\
\hline latitude & varchar \\
\hline longtitude & varchar \\
\hline radius & decimal \\
\hline tanggal_perolehan & date \\
\hline jumlah_ruangan & int \\
\hline
\end{tabular}

Informasi mengenai gedung (tabel 1) diperlukan karena ruangan merupakan bagian dari gedung. Pemberian lokasi pada ruangan diperlukan agar dalam penerapan LBS dapat ditentukan ruangannya (tabel 2). Pada setiap ruangan akan diberikan titik lokasi dan diberikan radius tiap ruangan. Radius tiap ruangan digunakan lingkaran untuk membuatnya dan titik sebagai titik pusat lingkaran tersebut sehingga untuk fasilitas push pada LBS dapat dilakukan berdasarkan radius lingkaran yang ada.

Tabel 2. Tabel ruangan

\begin{tabular}{|c|c|}
\hline column_name & type \\
\hline id_ruangan & int \\
\hline id_gedung & int \\
\hline nama_ruangan & varchar \\
\hline luas & varchar \\
\hline photo & varchar \\
\hline Latitude & varchar \\
\hline
\end{tabular}


Setelah didapat informasi mengenai ruangan dengan penerapan LBS maka informasi yang ditampilkan adalah barang yang ada pada ruangan tersebut sehingga diperlukan data barang yang disimpan pada tabel 3 .

Tabel 3. Tabel barang

\begin{tabular}{ll}
\hline \multicolumn{1}{c}{ column_name } & \multicolumn{1}{c}{ type } \\
\hline id_barang & int \\
\hline id_ruangan & int \\
\hline Nama & varchar \\
\hline Jumlah & int \\
\hline
\end{tabular}

\subsection{Tahap Pengembangan Perangkat Lunak}

Model yang digunakan untuk pengembangan aplikasi dalam penelitian ini adalah Extreme Programming (XP) [8], berikut ini merupakan tahapannya:

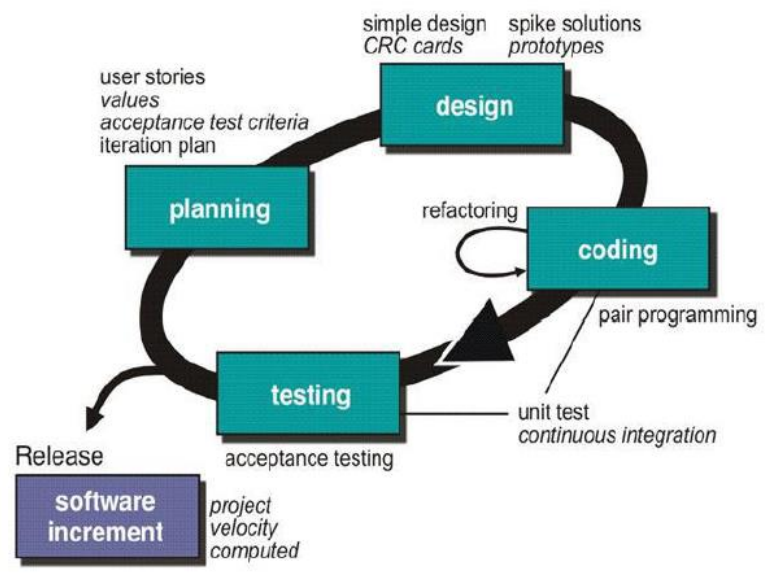

Gambar 1. Tahapan model Extreme Programming [8]

\section{Planning}

Pada tahap ini identifikasi dan analisis kebutuhan bisnis dilakukan. Begitupula kebutuhan pengguna dan kebutuhan sistem. Pembuatan user stories dari setiap kebutuhan dilakukan juga. User stories berfungsi sebagai dasar pembangunan sistem.

\section{Design}

Tahapan desain merupakan tahapan dimana user stories pada tahap planning diterapkan untuk membuat perancangan alur kerja dari sistem yang akan dibangun.

\section{Coding}

Tahap ini merupakan tahapan implementasi atau pembuatan kode program sesuai dengan rancangan sistem yang dibuat pada tahap sebelumnya. Tahap ini dapat dilakukan secara iteratif (code refactoring) jika terdapat perubahan. 


\section{Testing}

Pada tahapan ini dilakukan pengujian perangkat lunak/sistem. Pengujian dilakukan pada setiap modul yang sedang dibuat. Hal tersebut bertujuan untuk memastikan sistem yang dikembangkan sesuai dengan permintaan dan kebutuhan pengguna/klien. Sehingga perbaikan modul dapat dilakukan sampai modul yang dikembangkan sesuai dengan permintaan.

\section{Hasil dan Pembahasan}

Hasil dari penelitian ini adalah aplikasi pencatatan aktivitas mahasiswa menggunakan webservice dengan metode pengembangan perangkat lunak Extreme Programming yang terdiri dari beberapa tahapan yaitu planning, design, coding, testing.

\subsection{Planning}

Pada tahap ini dilakukan analisis kebutuhan bisnis dan kebutuhan sistem dalam penggunaannya. User stories akan dibuat berdasarkan kebutuhan pelanggan. User stories berfungsi sebagai dasar pembuatan aplikasi. Berikut adalah user stories yang telah dibuat.

\begin{tabular}{ll}
\multicolumn{1}{c}{ Tengguna/User } & \multicolumn{1}{c}{ Tabel 4. User Stories } \\
\hline Admin & $\begin{array}{l}\text { Admin merutuhan Sistem } \\
\text { halaman Kelola data gedung, ruangan, barang, dan user. }\end{array}$ \\
\hline User & $\begin{array}{l}\text { User merupakan pengguna yang dapat memanfaatkan fasilitas untuk } \\
\text { pengenalan ruangan dengan memanfaatkan LBS }\end{array}$ \\
\hline
\end{tabular}

Admin pada aplikasi ini untuk melakukan pengelolaan informasi mengenai gedung, ruangan, dan barang, serta user. User pada aplikasi ini menjalankan aplikasi untuk mendapatkan informasi mengenai barang yang ada pada ruangan di gedung yang datanya telah di inputkan oleh admin.

Fasilitas pencarian informasi sangat diperlukan dalam pembuatan sistem [9]. Cara mendapatkan informasi pada LBS ini, terbagi atas dua bagian yaitu dengan cara push dan pull. Untuk push dilakukan berada pada lokasi yang sudah ditentukan titiknya dalam radius tertentu dan secara otomatis sistem LBS akan memberikan informasi tanpa harus meminta informasi tersebut. Pada pull informasi diberikan oleh LBS sesuai dengan permintaan pengguna. Informasi yang diberikan pun dapat memberikan rute bagi pengguna untuk sampai pada lokasi ruangan yang dituju dari posisi pengguna, hal tersebut telah dilakukan pada penelitian sebelumnya [10][11].

\subsection{Design}

\section{1) Use Case}

Diagram use case digunakan untuk menggambarkan user yang menggunakan sistem dan perilaku user terhadap aplikasi. Use case digunakan untuk mendeskripsikan fasilitas-fasilitas pengguna yang dapat dilakukan sistem berdasarkan hak akses [12][13]. Untuk mengetahui sifat dari aplikasi yang akan dibuat dilakukan pemodelan proses bisnis menggunakan Use Case Diagram [14][15]. 


\section{JURNAL TEKNOLOGI INFORMASI}

Jurinal Keilmutan dein Aplikasi Bidang Teknik Informatilka

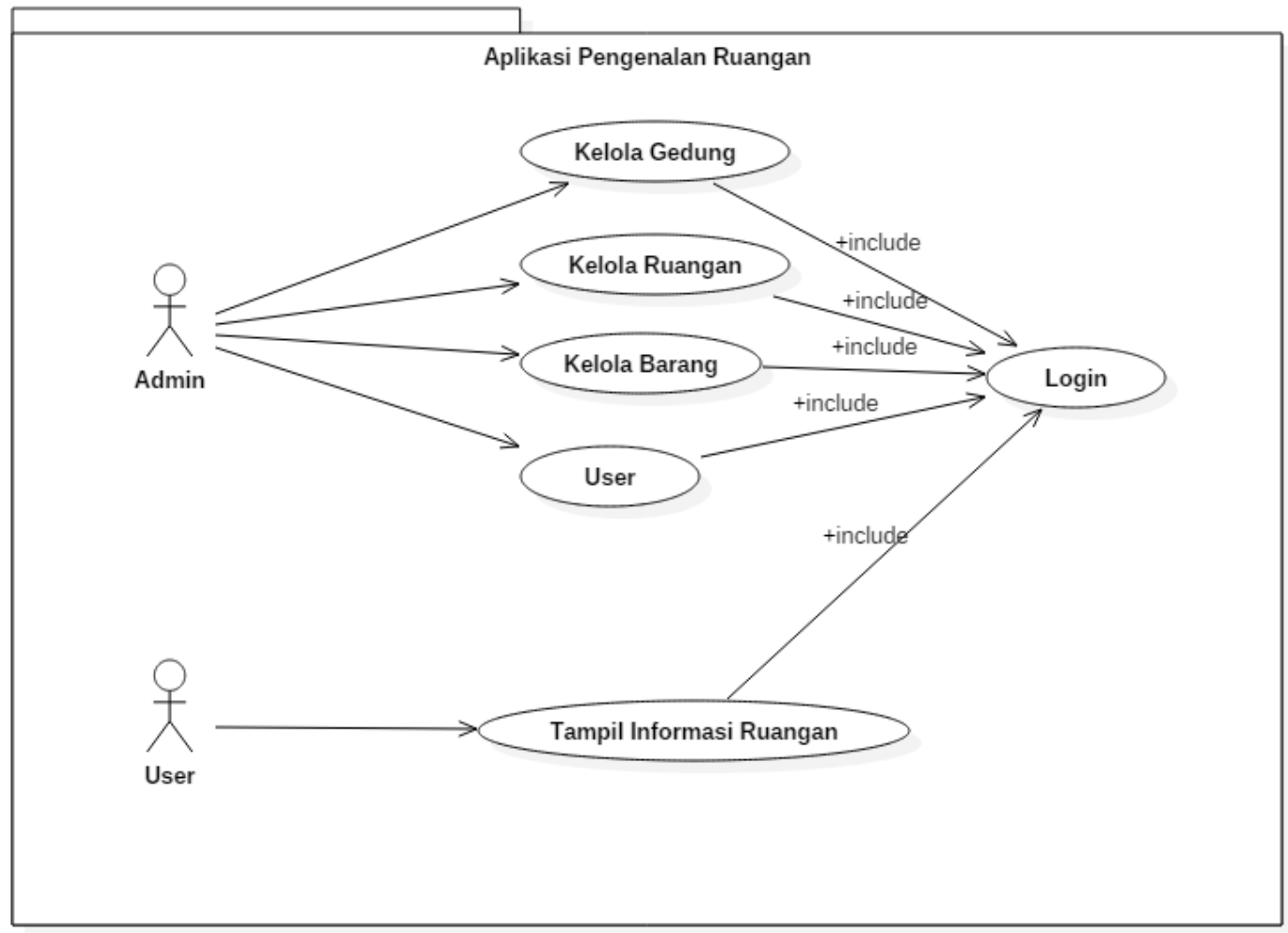

\subsection{Coding}

Gambar 2. Use Case Diagram Aplikasi

Pada tahap ini mengimplementasikan seluruh rancangan desain yang sudah dilakukan sebelumnya ke dalam Bahasa pemrograma. Pada bagian coding ditunjukkan dengan menampilkan hasil running dari programnya [16]. Pembuatan halaman Kelola gedung, ruangan, barang, dan user dilakukan penulis setelah menu utama dan login aplikasi telah dibuat. Berikut ini merupakan contoh halaman login dan Kelola ruangan yang dapat diimplementasikan pada saat coding.

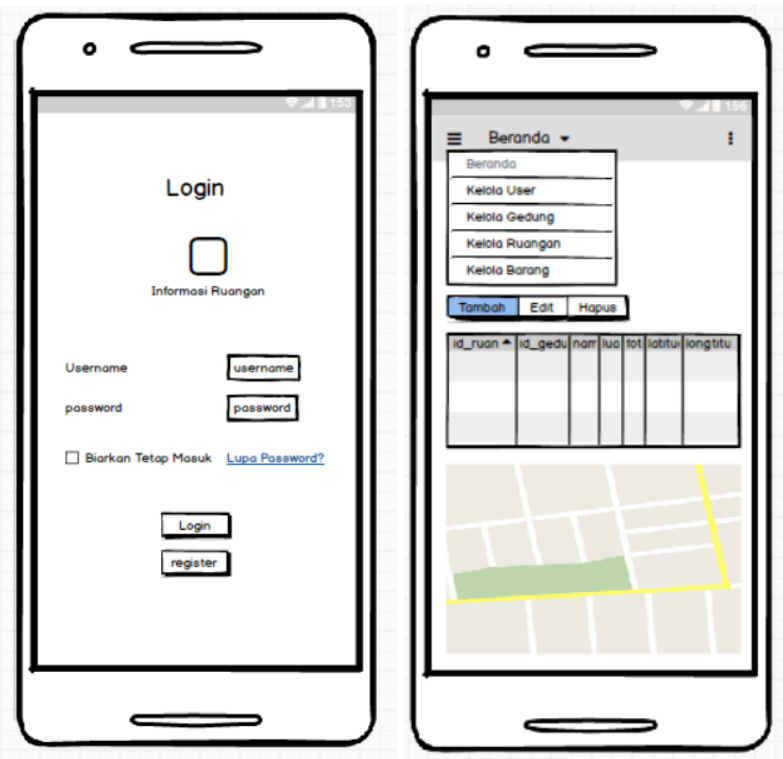

Gambar 3. Halaman Login dan Kelola Ruangan 
Tampilan halaman Kelola menampilkan data sesuai dengan data yang dikelolanya dan memiliki tombol tambah, edit, dan hapus yang digunakan untuk mengelola data. Untuk tampilan pengguna setelah melakukan login ditampilkan peta beserta textbox untuk mencari lokasi dengan tombol carinya. (gambar 4). Tampilan Peta juga digunakan pada halaman tersebut. Pada saat pengguna melewati ruangan maka akan ditampilkan notifikasi dan pop up dari peta berisi informasi dari ruangan yang dilalui.

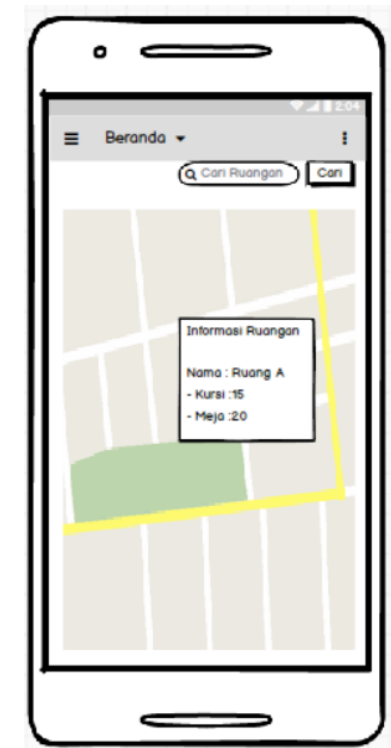

Gambar 4. Halaman Tampil Ruangan

\subsection{Testing}

Testing atau pengujian merupakan elemen kunci dari XP. Pengujian dilakukan untuk dapat memastikan apakah aplikasi dapat berjalan dengan baik dan benar sesuai dengan kebutuhan dan tujuan yang diharapkan [17]. Oleh sebab itu diperlukan pembuatan formular untuk menguji halamanhalaman yang ada pada aplikasi. Pembuatan formular tersebut didasari dari metode black box testing. Metode tersebut menguji dari tampilan antarmuka yang ada.

Tabel 5. Pengujian Halaman Kelola Gedung

\begin{tabular}{cllc}
\hline No. & Halaman Kelola Gedung & \multicolumn{1}{c}{ Proses } & Hasil \\
\hline $\mathbf{1}$ & \multicolumn{1}{c}{$\mathbf{2}$} & $\mathbf{3}$ & $\mathbf{4}$ \\
\hline 1 & Tombol Tambah & Tekan tombol Tambah \\
2 & Tombol Edit & Tekan tombol Edit \\
3 & Tombol Hapus & Tekan tombol Hapus \\
4 & Tampilan Halaman & Load Halaman \\
\hline
\end{tabular}

Pada saat memanggil halaman Kelola Gedung (lihat tabel 5) terdapat empat hal yang dapat diuji. Pengujian pada tabel 5 dapat digunakan juga untuk menguji halaman Kelola Ruangan, Barang, dan User. Pada halaman tampil informasi ruangan (lihat tabel 6) pengujian dilalkukan dengan melakukan pencarian dan berada pada radius yang telah ditentukan pada tabel ruangan sehingga informasi ruangan dapat ditampilkan. 
Tabel 6. Pengujian Halaman Tampil Informasi Ruangan

\begin{tabular}{cccc}
\hline No. & Halaman Kelola Gedung & Proses & Hasil \\
\hline $\mathbf{1}$ & $\mathbf{2}$ & $\mathbf{3}$ & $\mathbf{4}$ \\
\hline 1 & Tombol Pencarian & \multicolumn{2}{c}{ Tekan tombol Pencarian } \\
2 & Tampilan Halaman & \multicolumn{2}{c}{ Load Halaman } \\
\hline
\end{tabular}

Pada saat memanggil halaman login (lihat tabel 7) terdapat tiga hal yang dapat diuji.Penekanan tombol login setelah melakukan pengisian username dan password. Lalu menampilkan halaman registrasi pengguna dan menampilkan halaman login.

Tabel 7. Pengujian Halaman Login

\begin{tabular}{clcc}
\hline No. & Halaman Kelola Gedung & Proses & Hasil \\
\hline $\mathbf{1}$ & $\mathbf{2}$ & $\mathbf{3}$ & $\mathbf{4}$ \\
\hline 1 & Tombol Login & Tekan tombol Login \\
2 & Tombol Register & Tekan tombol Register \\
3 & Tampilan Halaman & Load Halaman \\
\hline
\end{tabular}

\section{Kesimpulan}

Berdasarkan penelitian yang dilakukan maka diambil kesimpulan sebagai berikut :

Penerapan LBS dilakukan pada saat memanggil halaman informasi ruangan yang berfungsi untuk mencari lokasi ruangan dan menampilkan notifikasi dan informasi ruangan pada saat pengguna masuk dalam radius yang telah ditentukan pada data ruangan tersebut. Penentuan radius sangat penting dilakukan sehingga informasi mengenai ruangan yang ditampilkan tidak beririsan dengan ruangan yang lainnya.Hal tersebut dilakukan untuk menjaga informasi ruangan yang tampil pada pengguna hanya menampilkan informasi satu ruangan saja. Oleh sebab itu pada saat menentukan radius ruangan harus ditentukan dengan seksama sehingga radius tersebut dapat membuat lingkaran yang tak beririsan dengan lingkaran radius lainnya.

Informasi ruangan yang ditampilkan didapatkan dari pengelolaan data oleh admin melalui halaman kelola gedung, ruangan, dan barang. Dalam melakukan pengelolaan, admin dapat menambah, mengedit, dan menghapus data.

Tahapan yang dilakukan dalam pembuatan prototipe aplikasi ini menggunakan model XP yaitu planning, design, coding, dan testing. Pengujian black-box dapat dilakukan dengan menjalankan langkah-langkah yang telah diberikan di format tabel pengujian sebelumnya. Sehingga untuk memastikan aplikasi berjalan dengan baik dapat ditentukan dari keberhasilan dalam melakukan pengujian.

Prortotipe yang dibuat memerlukan koneksi internet dan harus menghidupkan GPS pada ponsel sehingga aplikasi dan penerapan LBS pada GIS dapat berjalan dengan semestinya. Pengembangan aplikasi selanjutnya dapat ditambahkan fasilitas mengenai aktifitas atau kegiatan pada ruangan tersebut. Sehingga informasi yang ditampilkan pada ruangan menjadi lebih lengkap.

\section{Daftar Pustaka}

[1] Pranatawijaya, V.H. dan Saragih A.S. (2015). Analisis dan Desain Location Based Service Pada Jurusan Teknik Informatika Fakultas Teknik Universitas Palangka Raya. Jurnal Teknologi Informasi 9 (1), 1-8. 
[2] Pranatawijaya, V.H., dkk. (2018). Penerapan Location Based Service Pada Jurusan Teknik Informatika Fakultas Teknik Universitas Palangka Raya. Jurnal Teknologi Informasi 12 (1), 70-80.

[3] Pranatawijaya, V.H. (2014). Penerapan Google Maps API Pada Sistem Informasi Geografis (SIG) Tempat Wisata Dan Rekreasi Kota Palangkaraya Berbasis Web. Jurnal Teknologi Informasi 8 (1), 53-58.

[4] Pranatawijaya, V.H., dkk. (2018). Rancang Bangun Aplikasi Pemetaan Gedung Universitas Palangka Raya pada Sub. Bag Barang Milik Negara (BMN) BUK Universitas Palangka Raya. 12 (2), 74-79.

[5] KBBI, 2020. Kamus Besar Bahasa Indonesia (KBBI). [Online] Available at: http://kbbi.web.id/ruangan [Diakses 9 Desember 2020].

[6] PBAA, Putra; Pranatawijaya, VH; NNK, Sari. (2020). Implementasi Location Based Service Pada Aplikasi Mobile Penyajian Ruang Ujian. Jurnal Sains dan Informatika: Research of Science and Informatic 6 (1), 2630 .

[7] Pranatawijaya, V.H., dkk. (2019). Penerapan Skala Likert dan Skala Dikotomi Pada Kuesioner Online. Jurnal Sains dan Informatika 5 (2), 128-137.

[8] R. V. Anand and M. Dinakaran. (2016). Popular Agile Methods in Software Development: Review and Analysis. Int. J. Appl. Eng. Res. ISSN, vol. 11, no. 5, pp. 973-4562.

[9] PBAA, Putra; Pranatawijaya, VH; Widiatry, W; Lisa, L. (2017). Rancang Bangun Sistem Informasi Pencarian Data Mahasiswa Dan Dosen Pada Fakultas Hukum Universitas Palangka Raya. Jurnal Teknologi Informasi 11 (2).

[10] Pranatawijaya, V.H. (2019). Rancangan Aplikasi Bergerak Penjadwalan Distribusi Sembako pada UD. Kuning Mas Palangka Raya. Jurnal Teknologi Informasi 13 (2), 60-69.

[11] Pranatawijaya, V.H., dkk. (2018). Sistem Informasi Geografis Mencari Rute Lokasi Travel Di Kota Palangka Raya Berbasis Website. Jurnal Teknologi Informasi 13 (1), 76-82.

[12] Pranatawijaya, V.H. (2017). Pengembangan Perangkat Lunak Generate File Untuk Migrasi Data EPSBED Ke Format Table Feeder PDDIKTI. Jurnal SAINTEKOM 6 (1), 1-11.

[13]Pranatawijaya, V.H. (2017). Analisis Dan Desain Penerapan Location Based Service (LBS) Untuk Layanan Pengiriman Katering Di Kota Palangka Raya. Jurnal Teknologi Informasi 11 (2), 46-53.

[14] Pranatawijaya, V.H., dkk. (2017). Implementasi Algoritma Genetika Pada Penjadwalan Program Profesional Jurusan Teknik Informatika Universitas Palangka Raya.Jurnal Sains dan Informatika : Vol.5 No. 2 (2019)90-98.

[15]PBAA, Putra; NNK, Sari; Pranatawijaya, VH. (2017). Analisis Dan Desain Website Monitoring Konsultasi Bimbingan Kartu Rencana Studi (KRS). Jurnal Teknologi Informasi 11 (1), 58-68.

[16] Pranatawijaya, V.H. (2020). Implementasi Augmented Reality Pada Menu Rumah Makan. Jurnal Teknologi Informasi 14 (1), 21-29.

[17]Pranatawijaya, V.H. (2020). Implementasi Pencatatan Aktivitas Mahasiswa Menggunakan Web Service Pada Feeder Pddikti Dengan Metode Extreme Programming. Jurnal Teknologi Informasi 14 (2), 179-188. 